\title{
BUTTERFLIES AND SKIPPERS OF WEST-CENTRAL ALBERTA
}

\author{
JAMES W. CASE and C. D. BIRD, Department of Biology, \\ University of Calgary, Calgary, Alberta, T2N $1 N 4$.
}

Until recently, very few extensive investigations into the natural history of west-central Alberta had been carried out. The prospect of a pipeline carrying arctic gas through the area and an interest in the impact of existing natural gas processing plants on the environment however, led to numerous ecology study programs. Although largely carried out for private companies, many of these environmental reports, such as the Canadian Arctic Gas Biological Report Series ${ }^{1}$ have been made public. These studies were largely inventory oriented and dealt with entire communities as well as single groups of birds, mammals and plants. One group about which very little has been published though, is the Lepidopterans, especially the butterflies and skippers. Several people have made collections of butterflies in different parts of we'stcentral Alberta during the past hundred years or so, and most of these specimens have been examined by the authors. Ted Pike, for example has collected extensively along highways 16 and 43, and also in the Hinton area. In addition, J.W. Case carried out field work on butterfly faunistics throughout west-central Alberta while conducting research into air pollution impact around natural gas plants. It is this on which the present paper is largely based.

As defined here, west-central Alberta, a moderate to strongly rolling region, lies between 53 to 57 degrees north latitude and 114 to 120 degrees west longitude (Fig. 1) and comprises roughly 135,000 square kilometres. Rising 300-600 m above the lowlands is a series of flat-topped dissected plateaux known collectively as the Swan Hills. A small portion of the Rocky Mountains is included in the extreme southwest part of the study area. The majority of the area is drained by the Peace River. Most of the remainder is in the Athabasca River Watershed, while the rest in is the North Saskatchewan River Watershed.

The area is biologically diverse and complex. In the extreme northwest are the unique Peace River parklands which have close floristic similarities to the aspen parkland to the south and east. The Peace River grassland is dominated by wheat grass (Agropyron dasystachyum) and needle grass (Stipa spartea), which are found on dry south-facing slopes and well drained hill tops. June grass, prairie crocus, pasture sagewort, showy locoweed, and fragile pricklypear cactus are also found here. Aspen groves occur in moister or more sheltered places in the grasslands. Many shrubs and herbs occur within and around these aspen bluffs including Saskatoon-berry, roses, chokecherry, pin cherry, buckbrush, wild sarsaparilla, American vetch, yellow pea vine, northern bedstraw and wild strawberry. This parkland habitat supports several butterflies typical of the aspen parkland of southern Alberta, including the Dreamy Dusky Wing, Persius Dusky Wing, Gothic Swallowtail, Western Checkered White, Melissa Blue, Greenish Blue, White Admiral, Jenistai Fritillary, Mormon Fritillary, Common Wood Nymph Varuna Arctic, and Common Alpine. Sloughs are the place to look for the Bronze and Purplish Coppers.

In many areas, aspen dominates extensive stands of mixed forest with white spruce and lodgepole pine as subordinate tree species. The undergrowth is similar to that of the bluffs described above. Many butterflies are associated with these woods, including the Arctic Skipper, Northern Cloudy Wing, Mustard White, Large Marble, Scudder's Blue, Western Tailed Blue, Silvery Blue, 


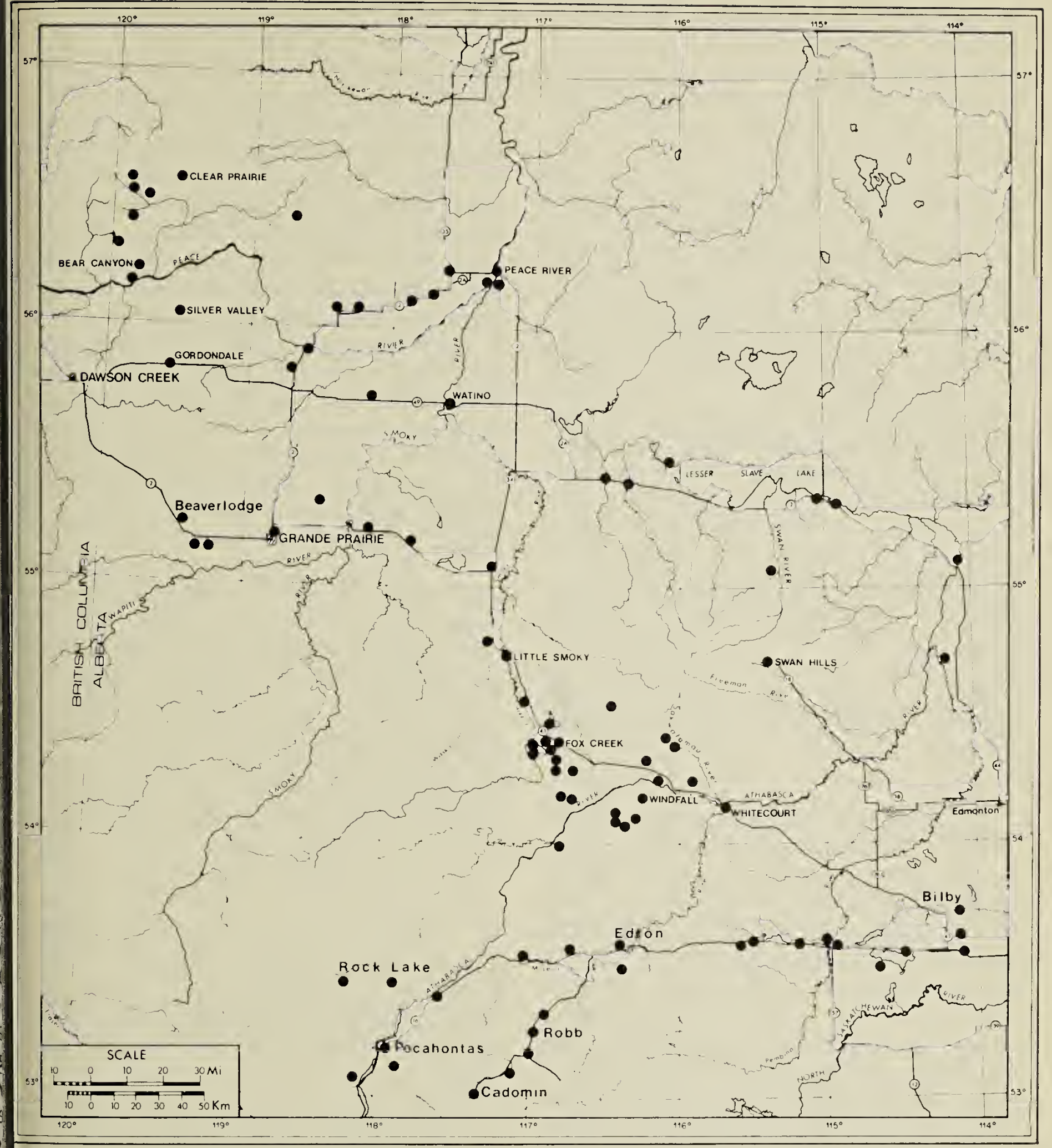

Fig. 1. Placenames and location of known butterfly collection sites in west-central Alberta.

Satyr Angle Wing, Gray Comma, Atlantis Fritillary, and Cary's Arctic.

Other parts of the study area are covered by mixed coniferous woods. Lodgepole pine dominated forest frequently occurs in well drained areas that have been burned over in the last century. Seedlings of white spruce, balsam fir and aspen are usually present in the understory. Many shrubs are also present, including low bush cranberry, blueberries, Labrador tea, bog cranberry, and thimbleberry (Rubus parviflorus). Common herbs here are twin-flower, bunchberry, Bishop's cap, goldthread (Coptis trifoliata), Prince's pine, oak-leaf fern (Gymnocarpium dryopteris), dewberry, fireweed and blue-joint grass (Calamagrostis canadensis). These forests are also the home of the Pinkedged Sulphur, Mariposa Copper, and Purple Lesser Fritillary.

Pines showing varying degrees of introgression with Jack pine occur in 
sand dune areas. A species poor understory is dominated by bearberry, hairy wild rye, harebell and Canada buffalo berry. Christina Sulphurs, Hoary Elfins, and Brown Elfins are found in this habitat.

White spruce forest is found over a wide range of edaphic conditions. Balsam fir, paper birch, aspen and lodgepole pine are frequently subordinate trees. A species rich understory frequently includes such interesting plants as common nettle, ground cedar (Lycopodium obscurum), stiff club-moss (L. annotinum), broad spinulose shield fern (Dryopteris dilatata), single delight (Moneses uniflora), Devil's club (Oplopanax horridum), false mitrewort (Tiarella trifoliata), gooseberries, red elder (Sambucus pubens), mountain ash, and twisted stalk (Streptopus amplexifolius). Butterflies found in or near these woods include the Hudsonian Old World Swallowtail, Green Comma, Atlantis Fritillary and Macoun's Arctic.

Black spruce dominates gentle slopes or undulating terrain with poorly drained soils. In very poorly drained places black spruce - peat moss bogs occur. Characteristic species of this complex are tamarack (Larix laricina), cloudberry (Rubus chamaemorus), swamp laurel (Kalmia polifolia), bog Rosemary (Andromeda polifolia), small bog cranberry (Oxycoccus microcarpus) and swamp birch. In better drained places, feather mosses dominate an understory otherwise made up largely of Labrador tea and reindeer lichen (Cladonia spp.). Black spruce dominated woods or bogs are the place to watch for the Giant Sulphur, Dorcas Copper, Bog Fritillary, Frigga Fritillary, Jutta Arctic and Mancinus Alpine.

Various stages of primary succession occur on stream and river flood plains. The Spring Azure is often abundant in such areas of riverine forest.

The extreme southwestern part of the study area includes a portion of the Rocky Mountains in Jasper
National Park. Many butterflies found in this area are found nowhere else in western central Alberta. These upper foothills, subalpine and alpine areas were not visited by the authors and our knowledge of the butterfly fauna of the area is limited largely to specimens taken in the vicinity of Pocahontas by K. Bowman in the first part of the century. Future work in this area will undoubtedly reveal several mountain species besides the ones that are known from the area which include the following: Manitoba Skipper, Elis Sulphur, Astraea Sulphur, Nastes Sulphur, Creusa Marble, Hewitson's Checkerspot, Bean's Checkerspot, Hydaspe Fritillary, Bean's Arctic and Bruce's Arctic.

In addition to the natural habitats, man has produced a variety of new ones such as cultivated land, weedy clearings, farm yards, roadsides, seismic lines and pipeline right-ofways. This has destroyed some natural habitat, and clearing of farm land has done the majority of that, but a multitude of new clearings has resulted where butterflies abound, feeding on flowers of alfalfa, clover and weeds. The borders of a road through aspen or mixed woods are an especially good place to watch for the Alfalfa Butterfly, Silvery Blue, Cabbage White, Greenish Blue, Long Dash Tawny-Edged Skipper and Red Admirals.

The earliest known butterfly collec tions in west central Alberta were made near Peace River in 1893, by an unknown collector whose specimens are now preserved in the Canadiar National Collection. James Fletchel collected a Northwestern Silverspot also in the Peace River area presumably around 1903, eithe before or after visiting F. H. Wolle) Dod in Calgary. W. Klassen collected a Tiger Swallowtail at Beaverlodge ir June of 1910. Between 1913 and 1925 $\mathrm{K}$. Bowman made many collection: near Pocahontas, Cadomin, Bilby Beaverlodge, Coalspur and Wembley Donald Mackie collected a large number of butterflies, including Coral Hairstreak, near Bilby from 192 
to 1925 . O. Bryant also made collections near Bilby in 1924 In 1940, C. L. Neilson collected several butterflies at Dunvegan, Brownvale, Fairview, Bluesky, Beaverlodge and Huallen. Ten years later, $L$. Burgess made a few collections near Beaverlodge. B. Hocking made collections near Wabamun in 1955 and Sundance in 1957. More recently, collections have been made by R. L. Anderson at Edson in 1958; D. Hughes, A. Pucat, $M$. A. MacGregor and F. D. Johanson at Flatbush in 1960; S. L. Skaley at Rycroft in 1966; J. Emond near Little Smoky in 1968; Brian Randall at Grande Prairie in 1968; R. Carcasson at Goodwin in 1969; Peter Kuchar near Vine Creek in 1970; Ted Pike at Grimshaw, Canyon Creek, Slave Lake, along highways 43 and 16, and in the Hinton area from 1972-77; J. Belicek near Nojack in 1973; C. D. Bird near Robb in 1974; G. J. Hilchie near Enilda in 1975 and near Little Smoky in 1977; W. Smith at Hilliard's Bay on Lesser Slave Lake in 1976; Vanny Case near Little Smoky in 1977; Bill Hills near Peace River in 1977; and J. W. Case throughout the area from 1974 to 1977.

\section{SPECIES LIST}

The common and scientific names employed are essentially those of Hooper's "Butterflies of Saskatchewan". ${ }^{3}$ Dates listed after the species are the known flight periods. Moss' "Flora of Alberta"6 is the reference for the plant names. Records are of specimens taken by J. W. Case, unless another collector's name is given in parentheses. Sight records (SR) of the authors are also included.

\section{HESPERIIDAE - SkIppers}

PECK'S SKIPPER (Polites coras). July 23-24. Found in grassy clearings in white spruce and lodgepole pine woods. Known from Bilby (D. Mackie) and $46 \mathrm{~km} \mathrm{~S}$ of Fox Creek.

TAWNY-EDGED SKIPPER (Polites themistocles). July $2-4$. Found rarely along roadsides in parkland areas. Known only from collections made at Bilby in 1924 by D. Mackie and O. Bryant.

LONG DASH (Polites sonora dacotah). June 29. A single, fresh male was taken in 1975 in a grassy clearing surrounded by aspen woods, $1 \mathrm{~km}$ NW of Little Smoky.
MANITOBA SKIPPER (Hesperia comma manitoba). Found in mountain meadows. Known only from near Pocahontas where a single male was collected by K. Bowman in June, 1918.

ARCTIC SKIPPER (Carterocephalus palaemon). May 29-July 1. Found along trails and in clearings bordered by aspen or mixed woods where it visits many different flowers. It has been collected in the Fox Creek area, near Little Smoky, and along the MacLean Creek $30 \mathrm{~km} \mathrm{~N}$ of Bear Canyon. Specimens taken at Bilby by D. Mackie in 1921, 1922 and 1925 were labelled as Carterocephalus palaemon mesapano but all of the other specimens more closely resemble Carterocephalus palaemon mandan. The differentiation between these subspecies has been based on size differences with the larger mandan occurring in the mountains and the boreal forest, while the smaller mesapano is found in the aspen parkland and prairies. Too much size overlap occurs to justify the recognition of two subspecies in the area at this time.

NORTHERN CLOUDY WING (Thorybes pylades). June 3-June 22. Found occasionally in moist mixed woods where the larval food plants, yellow pea vine and vetches, are abundant. Known from Little Smoky, along the Waskahigan River near Little Smoky, and Hilliard's Bay on Lesser Slave Lake (W. Smith).

ALPINE CHECKERED SKIPPER (Pyrgus centaurae loki). July 2-12. Purportedly found in foothills forest and alpine meadows. It is known in the study area from collections made by K. Bowman at Pocahontas in 1913 and 1921.

DREAMY DUSKY WING (Erynnis icelus). May 16-July 7. Found commonly along the edges of aspen and mixed woods. It has been collected at Bilby (D. Mackie), $20 \mathrm{~km}$ NNW of Whitecourt, in the Fox Creek area, $25 \mathrm{~km} \mathrm{NW}$ of Fox Creek, Little Smoky, Pocahontas (K. Bowman), along MacLean Creek $30 \mathrm{~km} \mathrm{~N}$ of Bear Canyon, and $23 \mathrm{~km}$ WSW of Clear Prairie.

PERSIUS DUSKY WING (Erynnis persius). May 29-July 1. Found occasionally along the edges of aspen woods where it feeds on early flowering legumes. It has been collected near Fox Creek, Goodwin ( $R$. Carcasson). Pocahontas (K. Bowman), and along MacLean Creek $30 \mathrm{~km}$ N of Bear Canyon.

\section{PAPILIONIDAE - Swallowtalla}

GOTHIC SWALLOWTAIL (Papilio zelicaon gothica). May 19-July 6. Found occasionally on dry hill tops or meadows in parkland. It is known from Billby (D. Mackie), Nojack 


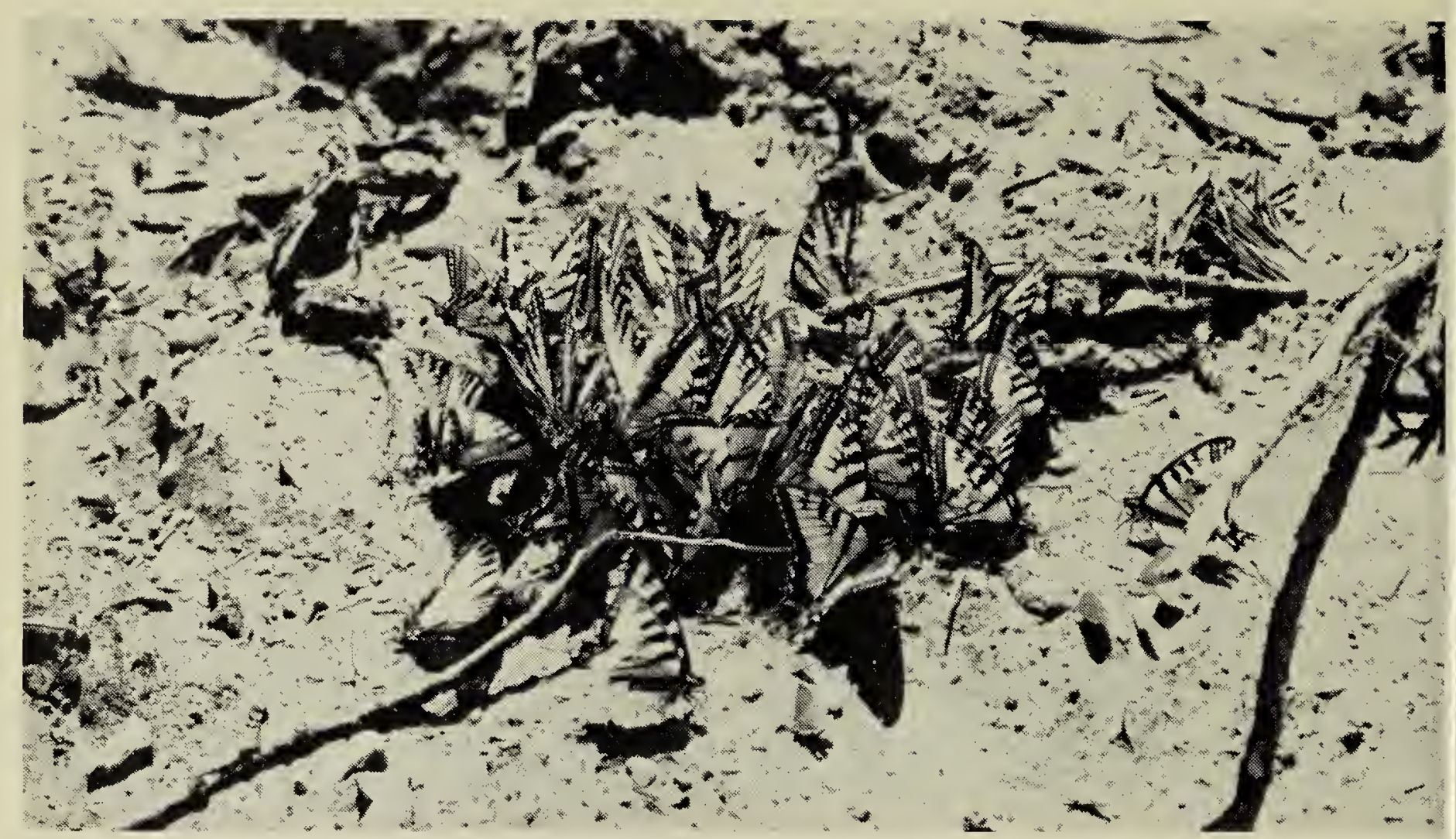

James W. Case

A Tiger Swallowtail mud puddle club. These butterflies are swarming around a small puddle, apparently as a result of a craving for the salts present in such moist places. Note the Blues that are trying to join the club.

(J. Belicek), the Fox Creek area and along MacLean Creek $30 \mathrm{~km} \mathrm{~N}$ of Bear Canyon. This species was usually found flying with Tiger Swallowtails but was easily spotted because it appears distinctly darker than its companions.

\section{HUDSONIAN OLD WORLD} SWALLOWTAIL (Papilio machaon hudsonianus). May 29-July 22. Found in aspen parkland woods and in mixed woods. It is known from $6.4 \mathrm{~km}$ SW of Fox Creek, the Kleskun Hills, the Peace Hills $7 \mathrm{~km} S$ of Bear Canyon and $30 \mathrm{~km} \mathrm{~N}$ of Bear Canyon.

TIGER SWALLOWTAIL (Papilio glaucus canadensis). May 22-July 4. One of the commonest, and certainly one of the most obvious, butterflies anywhere, especially near aspen woods. It visits Labrador tea, clover, gardens and weedy roadsides. It is known from Bilby (D. Mackie), Pocahontas (K. Bowman), $2 \mathrm{~km}$ W of Nojack (T. Pike), $25 \mathrm{~km} \mathrm{NW}$ of Whitecourt, the junction of the Athabasca River and Pine Creek (SR), Fox Creek, Little Smoky, along the Waskahigan River near Little Smoky, near Crooked Creek (T. Pike), near Peace River, $30 \mathrm{~km} \mathrm{~N}$ of Bear Canyon and Boundary Lake.

The first author experienced what could only be a classical case of simultaneous emergence of these butterflies in the late morning of July 1, 1976, $30 \mathrm{~km} \mathrm{~N}$ of Bear Canyon. The area had been visited the previous day and a few average - worn specimens were seen, but the next day it seemed to be snowing Tiger Swallowtails. Most were fresh and many "puddle clubs" were observed during the next few days. Females were also seen laying eggs on aspen leaves.

\section{PIERIDAE - Whites, Sulphurs and Marbles}

WESTERN CHECKERED WHITE (Pieris protodice occidentalis). August 12September 8 . Found commonly in open parkland, usually in disturbed areas, where weedy mustards abound. It is known from Bilby (D. Mackie), $30 \mathrm{~km} \mathrm{NW}$ of Whitecourt, along Marsh Head Creek, Rycroft (L. Skaley), and Boundary Lake.

MUSTARD WHITE (Pieris napi oleracea). May 22-August 12. Found in open areas in white spruce or mixed woods. It is known from Bilby (D. Mackie), George Lake ( $T$. Pike), Lesser Slave Lake (T. Pike), Hilliard's Bay on Lesser Slave Lake (W. Smith), $19 \mathrm{~km}$ $W$ of Wildwood (T. Pike), the gas plant near Fox Creek, $6.4 \mathrm{~km}$ SW of Fox Creek, $45 \mathrm{~km}$ SE of Fox Creek, $9.7 \mathrm{~km}$ SE of Pass Creek Forestry Tower, and Hondo (G. Hilchie). There is some indication that the ecologial range of this species is being reduced as a result of competition with the introduced European Cabbage White, just as some of the local bird populations are suffering because of the starling invasion. CABBAGE WHITE (Pieris rapae). July 15- 
August 27. Found in gardens, fields and in forest clearing. It has been collected near Evansburg (T. Pike), Whitecourt, Silver Valley and Grande Prairie, but has been observed throughout the area south of the Peace River. This species was accidentally introduced into Quebec in about 1860 and rapidly spread throughout North America (Howe 1975). It has been a serious pest of cruciferous crops and is also replacing Pieris napi in many places.

PALAENO SULPHUR (Colias palaeno chippewa). June 11-July 12. This northern species has been occasionally picked up in the southern parts of the study area, but is more common near the mountains in the west. It is found in or near boggy areas where the food plants, Vaccinium species, occur. It is known from collections made by T. Pike in the vicinities of Evansburg, Nojack, Rock Lake and Cadomin.

ELIS SULPHUR (Colias meadii). August 18-30. This mountain species has been taken only in that part of the study area lying within Jasper National Park. K. Bowman found it at Pocahontas in 1915 and P. Kuchar collected it 55 years later along Vine Creek.

ALFALFA BUTTERFLY (Colias eurytheme eurytheme). June 12-July 12 . Found rarely in agricultural areas where clover and alfalfa are cultivated. It has been collected once at Beaverlodge (D. Mackie) and twice $30 \mathrm{~km} \mathrm{~N}$ of Bear Canyon.

ALFALFA BUTTERFLY (Colias eurytheme var. alberta). Several specimens taken previously have been labelled as Colias eurytheme var. alberta. K. Bowman, who described this variety, collected several specimens in the Beaverlodge - Wembley area during 1924-25. C. L. Neilson took it again at Brownvale and Beaverlodge in 1940. It seems likely that all of these specimens are hybrids between Colias alexandra christina and Colias eurytheme eurytheme. Ferris ${ }^{2}$ came to a similar conclusion. There have been no recent collections or observations of anything resembling these specimens.

ALFALFA BUTTERFLY (Colias philodice eriphyle). June 11-September 9. Found throughout the area, especially where pipeline right-of-ways, ditches and fields are seeded to clover and alfalfa. It has been collected at Boundary Lake, along MacLean Creek $30 \mathrm{~km} \mathrm{~N}$ of Bear Canyon, $19 \mathrm{~km} \mathrm{NW}$ of Whitecourt, $5 \mathrm{~km}$ W of Edson (T. Pike), Little Smoky, in the Fox Creek area, $9.7 \mathrm{~km}$ SE of Pass Creek Forestry Tower, Eureka River, $40 \mathrm{~km}$ NW of Whitecourt, $30 \mathrm{~km}$ WNW of Whitecourt, $35 \mathrm{~km} \mathrm{NW}$ of Whitecourt and $40 \mathrm{~km} \mathrm{~N}$ of Swan Hills, near Beach Corner (T. Pike) and in the Evansburg area (T. Pike).
PINK-EDGED SULPHUR (Colias interior interior). May 22-August 24. Found commonly along roads and trails through mixed woods where the larval food plants, Vaccinium spp., are common. K. Bowman collected this species at Pocahontas in 1921, and L. Burgess took it at Beaverlodge in 1950. Recently, it has been collected in the vicinities of Fox Creek, Little Smoky (Vanny Case), Robb (C. D. Bird), Boundary Lake, Bear Canyon and MacLean Creek 30 $\mathrm{km} \mathrm{N}$ of Bear Canyon.

GIANT SULPHUR (Colias gigantea gigantea). June 18-July 12 . Found occasionally in wet meadows near mixed woods or brushland dominated by willows, which are the food plants. It is known from the vicinities of Pocahontas (K. Bowman), Hondo (G. Hilchie), Bilby (D. Mackie), near Evansburg (T. Pike), $19 \mathrm{~km}$ W of Wildwood (T. Pike), near Crooked Creek (T. Pike), $8 \mathrm{~km}$ E of Whitecourt (T. Pike), $6 \mathrm{~km} E$ of Granada (T. Pike) and MacLean Creek $30 \mathrm{~km} \mathrm{~N}$ of Bear Canyon.

CHRISTINA SULPHUR (Colias alexandra christina). June 26-August 14 . Found at the edges of aspen or mixed woods where the food plants, legumes, are common. It is known from the vicinities of Beaverlodge (K. Bowman), Hinton (D. E. Scovell), MacLean Creek $30 \mathrm{~km} \mathrm{~N}$ of Bear Canyon, $22 \mathrm{~km} \mathrm{~N}$ of Bear Canyon, Wembley (K. Bowman), Beaverlodge (K. Bowman), Brownvale (C. L. Neilson), Robb (C. D. Bird), Coalspur (K. Bowman) and Pocahontas (K. Bowman).

ASTRAEA SULPHUR (Colias alexandra astraea). August 27. Purportedly found in open areas in foothills. It is known from the vicinities of Pocahontas (K. Bowman), Cadomin (T. Pike) and Shaw (T. Pike).

NASTES SULPHUR (Colias nastes streckeri). July 2 . This mountain species is found in alpine meadows and on ridges. It is known only from the vicinity of Pocahontas (K. Bowman).

CREUSA MARBLE (Euchloe creusa). June 19-July 12. Purportedly found in open coniferous woods and meadows. It is known from the vicinities of Pocahontas ( $\mathrm{K}$. Bowman), Rock Lake (T. Pike) and Cadomin (T. Pike).

LARGE MARBLE (Euchloe ausonides ausonides). May 29-July 11. Found commonly along roadsides and in mixed forest wherever there are wild or weedy mustards. It is known from the vicinities of Robb (T. Pike), $13 \mathrm{~km} \mathrm{~S}$ of Edson (T. Pike), Fox Creek, Hilliard's Bay on Lesser Slave Lake (W. Smith), Canyon Creek (T. Pike), Grimshaw (T. Pike), Bear Canyon, MacLean Creek $30 \mathrm{~km} \mathrm{~N}$ of Bear Canyon and Boundary Lake. 


\section{LYCAENIDAE - Gossamer-winged Butterflies}

CORAL HAIRSTREAK (Chrysophanus titus immaculosus). Purportedly found in open woods, ravines and valleys of the parkland where choke-cherry is common. It is known only from the vicinity of Bilby (D. Mackie).

HOARY ELFIN (Callophrys polios obscurus). April 15-May 28. Reported to occur in lodgepole pine woods on sand dunes. It is known from the vicinities of Bilby (D. Mackie), Pocahontas (K. Bowman) and Goodwin (R. Carcasson).

BROWN ELFIN (Callophrys augustinus). April 16-May 30. Found in black spruce woods and nearby open lodgepole pine woods where blueberry (Vaccinium spp.), bog laurel (Kalmia polifolia), bog cranberry (Oxycoccus microcarpus) and bearberry are available. It is known from the vicinities of Pocahontas (K. Bowman), Bilby (D. Mackie), near the losegun River campground and Fox Creek.

WESTERN ELFIN (Callophrys eryphon eryphon). April 17-May 30. Found in pine woods. It is known from the vicinities of Pocahontas (K. Bowman) and Fox Creek.

BRONZE COPPER (Lycaena thoe). July 10September 5 . Found in wet meadows. Known only from collections made by $D$. Mackie near Bilby between 1921-26.

MARIPOSA COPPER (Lycaena mariposa mariposa). July 10-August 3. Found occasionally in mixed coniferous woods on wet soil. It is known from the vicinities of Robb (C. D. Bird), Edson (R. L. Anderson) and MacLean Creek $30 \mathrm{~km} \mathrm{~N}$ of Bear Canyon.

PURPLISH COPPER (Lycaena helloides). July 19- August 3. Found around sloughs and marshes where the larval food plants, dock and knotweed, are found. It is known from the vicinities of Robb (C. D. Bird) and Bilby (D. Mackie).

DORCAS COPPER (Lycaena dorcas dorcas). July 1-July 9. Found in wet black spruce bogs or other marshy areas where Potentilla species grow. It is known from the vicinities of Boundary Lake, MacLean Creek $30 \mathrm{~km} \mathrm{~N}$ of Bear Canyon and High Prairie (G. Hilchie).

SCUDDER'S BLUE (Lycaeides argyrognomon scudderii). June 17-August 30 . Found commonly along roads through mixed woods and at the edges of aspen bluffs in parkland. It is known from the vicinities of Bilby (D. Mackie), Pass Creek Tower, Kleskun Hills, MacLean Creek 30 $\mathrm{km} \mathrm{N}$ of Bear Canyon, Robb (C. D. Bird), Cadomin (T. Pike), Shaw (T. Pike), Pocahontas (K. Bowman) and Vine Creek
(P. Kuchar).

MELISSA BLUE (Lycaeides melissa melissa). June 21 -July 22 . Found in virgin prairie areas of the Peace River parkland, which has all but disappeared. It is known from the vicinities of Wembley (K. Bowman), Sagitawa Lookout near Peace River, Grande Prairie and the Kleskun Hills.

GREENISH BLUE (Plebejus saepiolus amica). June 11-August 12. Found in parkland along roads, trails, cutlines, damp meadows and wasteplaces. It is known from the vicinities of Beach Corner ( $T$. Pike), Evansburg (T. Pike), Granada (T. Pike), Bilby (D. Mackie), Nojack (T. Pike), Whitecourt (T. Pike), Hilliard's Bay on Lesser Slave Lake (W. Smith), $40 \mathrm{~km}$ SE of Fox Creek, Pass Creek Tower, Little Smoky, Crooked Creek (T. Pike), Peace River, Gordondale, Kleskun Hills, Bear Canyon, MacLean Creek $30 \mathrm{~km} \mathrm{~N}$ of Bear Canyon and Boundary Lake.

YUKON BLUE (Plebejus optilete yukona). July 4-12. Rarely found in coniferous woods and bogs where bog cranberries (Vaccinium vitis and Oxycoccus micrococcus) are common. It is known from the vicinity of Bilby, where it was collected by D. Mackie and K. Bowman in 1922-23, and from $30 \mathrm{~km}$ SE of Little Smoky, where it was taken by G. Hilchie and T. Pike in 1977.

MEGALO ARCTIC BLUE (Plebejus aquilo megalo). June 8-July 14. Found near aspen or pine woods and in the mountains near the tree line. It is known from the vicinities of Beaverlodge (D. Mackie), Cadomin (T. Pike) and Pocahontas (K. Bowman).

WESTERN TAILED BLUE (Everes amyntula albrighti). May 29-July 28. Abundant in and around aspen or mixed woods where the food plants, which include vetches and yellow pea vine, are found. It is known from the vicinities of Bilby (D. Mackie), Nojack (T. Pike), Whitecourt (T. Pike), Fox Creek, Little Smoky, the Waskahigan River near Little Smoky, Rock Lake (T. Pike), Pocahontas (K. Bowman), Goodwin (R. Carcasson), Peace River, $33 \mathrm{~km} \mathrm{~W}$ of Watino, Gordondale, MacLean Creek 30 $\mathrm{km} \mathrm{N}$ of Bear Canyon, Bear Canyon and Boundary Lake.

SILVERY BLUE (Glaucopsyche lygdamus couperi). May 14-July 17. Found commonly in clearings in or near aspen and balsam poplar woods, where it feeds with Western Tailed Blues on legumes. It is known from the vicinities of Wabamun (B. Hocking), Sundance (B. Hocking), Bilby (D. Mackie), Beach Corner (T. Pike), Goodwin (R. Carcasson), Rock Lake (T. Pike), Pocahontas (K. Bowman), Fox Creek, Little Smoky, along the Waskahigan River near Little Smoky, Peace River, Bear Canyon, 


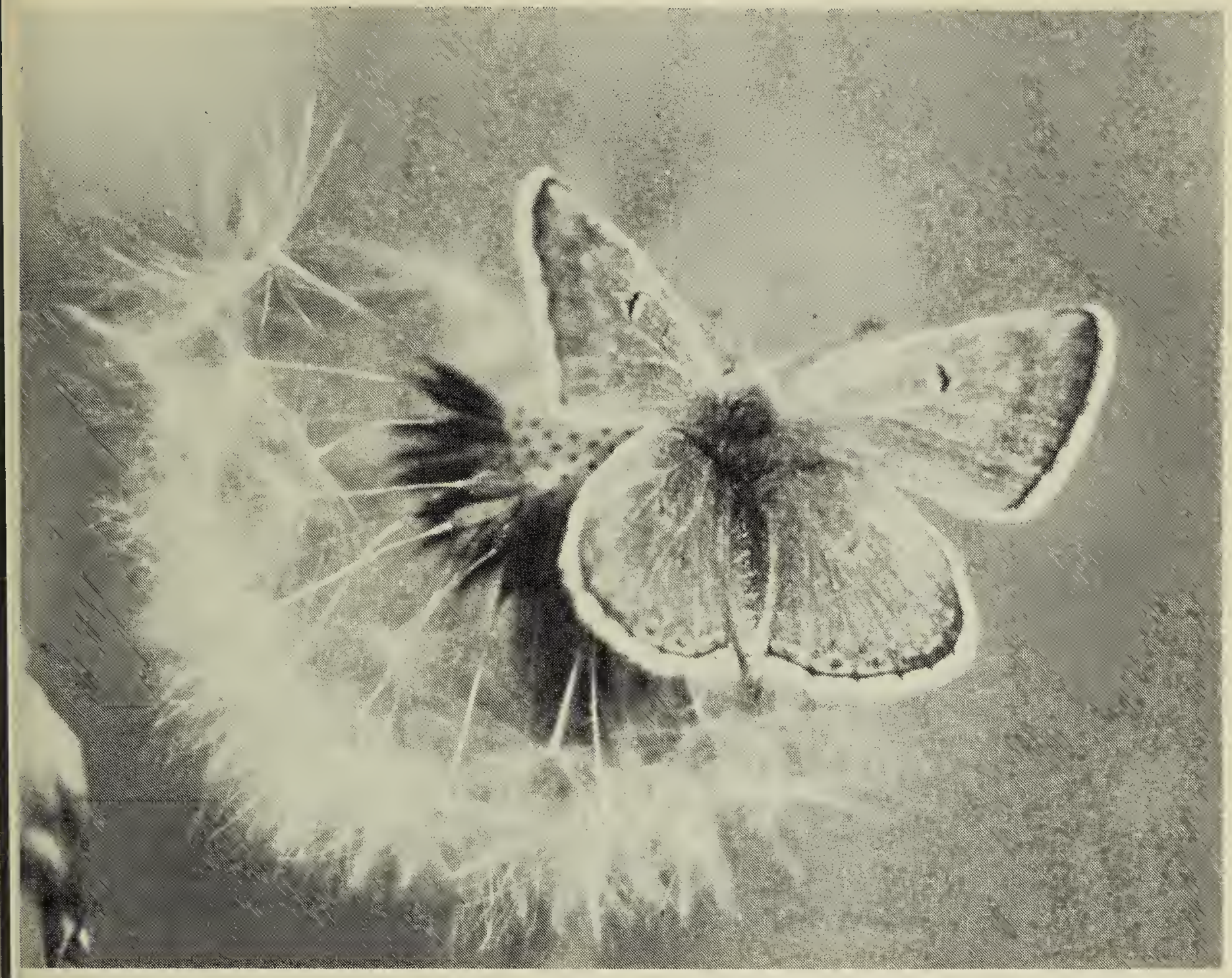

Greenish Blue

Gary Anweiler

Maclean Creek $30 \mathrm{~km} \mathrm{~N}$ of Bear Canyon and at Boundary Lake.

SPRING AZURE (Celastrina argiolus lucia). April 17-June 11. Found in poplar and mixed woods where it feeds on willows, strawberry and violets. It is known from the vicinities of Bilby (D. Mackie), Sundance (B. Hocking), the Sakwatimaw River about $20 \mathrm{~km}$ NNW of Whitecourt, $30 \mathrm{~km}$ NE of Windfall (SR), Fox Creek, Pine Creek, Little Smoky, near the losegun River campground and Pocahontas (K. Bowman).

\section{NYMPHALIDAE - Brush-footed Butterflies}

WHITE ADMIRAL (Limenitis arthemis rubrofasciata). June 29-August 15. Very common in aspen woods and along trails through such woods. It is known from the vicinities of Windfall (SR), Silver Creek (SR), Fox Creek, Peace River (SR), $33 \mathrm{~km} \mathrm{~W}$ of Watino, MacLean Creek $30 \mathrm{~km} \mathrm{~N}$ of Bear Canyon and at Boundary Lake.

RED ADMIRAL (Vanessa atalanta rubria). June 1 and October 9 . Found in farm yards and waste places. Known from Bilby (D.
Mackie) and near Peace River (Bill Hills). PAINTED LADY (Cynthia cardui). May 19. Known by several specimens taken by J. Belicek near Nojack. This species is rarely observed migrating into the area.

COMPTON TORTOISE SHELL (Nymphalis vau-album watsoni). August 7-September 17. Found occasionally in deciduous or mixed woods. It is known from the vicinities of Bilby (D. Mackie), and George Lake ( $T$. Pike). These specimens were labelled as Nymphalis vau-album j-album but according to G. A. Gorelick's treatment of the genus in, "The Butterflies of North America"t ${ }^{\prime \prime}$ the subspecies $j$-album is found in the eastern part of the (transcontinental) range while "The subspecies name watsoni (Hall) applies to those populations occurring in northern Wyoming, Montana, Alberta, British Columbia and Alaska"

MILBERT'S TORTOISE SHELL (Nymphalis milberti furcillata). May 21-September 17. Found commonly wherever the principal host plant, common nettle, is found. It is known from the vicinities of Swan Hills, Windfall (SR), Pine Creek, $14 \mathrm{~km} \mathrm{~W}$ of Fox Creek, MacLean Creek $30 \mathrm{~km} \mathrm{~N}$ of Bear 


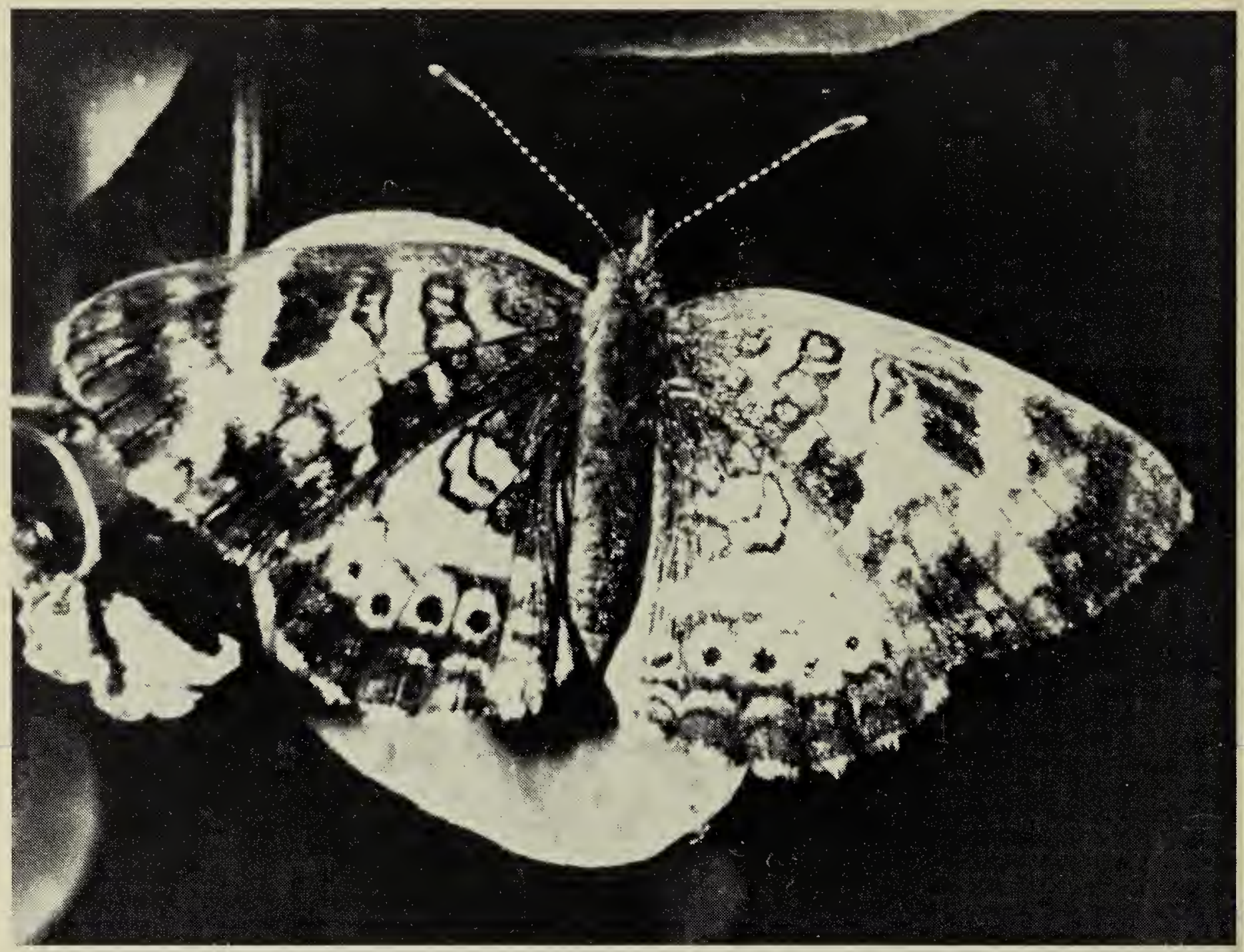

Pearl Crescent

Frank A. Switzer

Canyon and Eureka River.

MOURNING CLOAK (Nymphalis antiopa antiopa). May 5-September 5. Found commonly in aspen and mixed coniferous woods. It is known from the vicinities of Bilby (D. Mackie), Flatbush (M. A. MacGregor), Whitecourt (SR), Windfall $(S R)$, Fox Creek (SR), Smoke Lake (SR), the junction of the Athabasca River and Pine Creek (SR), Rock Lake (T. Pike), $32 \mathrm{~km} \mathrm{~S} \mathrm{of}$ Valleyview (J. Emond) and Beaverlodge (K. Bowman).

SATYR ANGLE WING (Polygonia satyrus satyrus). April 29-September 18. Found occasionally in mixed woods and alluvial forest communities where the larval food plants, nettles, are found. It is known from the vicinities of Bilby (D. Mackie), George Lake (T. Pike, P. Graham), Lesser Slav Lake (T. Pike), $30 \mathrm{~km} \mathrm{WNW} \mathrm{of} \mathrm{Whitecourt,} 47$ $\mathrm{km}$ SSE of Fox Creek, Little Smoky and Beaverlodge (L. Burgess).

ZEPHYR ANGLE WING (Polygonia zephyrus). May 5-August 28. Found rarely in white spruce woods where the larval food plants, wild currants and gooseberries, are found. It is known from the vicinity of George Lake (T. Pike), Lesser Slave Lake (T. Pike), Cadomin (K. Bowman), Rock Lake (T. Pike) and Pocahontas

\section{(K. Bowman).}

GRAY COMMA (Polygonia progne). April 23 -September 18 . Found in aspen woods or brushland where it lays its eggs on the leaves of wild currants and gooseberries. It is known from the vicinities of Wabamun (K. Bowman), George Lake (T. Pike), Bilby (D. Mackie), Cadomin (K. Bowman), and Pocahontas (K. Bowman).

GREEN COMMA (Polygonia faunus rusticus). April 29-June 21. Found in white spruce and mixed coniferous woods. It is known from the vicinities of Bilby (D. Mackie), George Lake (T. Pike), Flatbush (A. Pucat), Hilliard's Bay on Lesser Slave Lake (W. Smith), $35 \mathrm{~km} \mathrm{NW}$ of Whitecourt, $30 \mathrm{kn}$ WNW of Whitecourt, $19 \mathrm{~km} \mathrm{NW}$ of Whitecourt and Pocahontas (K. Bowman).

PEARL CRESCENT (Phyciodes tharos tharos). June 5-June 22, June 29-August 3. Found in meadows, along old trails at the borders of aspen woods and anywhere else asters grow. It is the most widespread butterfly and also one of the most abundant. It is known from the vicinities of Wabamun (D. Hocking), Bilby (D. Mackie), Granada (T. Pike), Evansburg (T. Pike), Whitecourt (T. Pike), Fox Creek, Little Smoky, along the Waskahigan River near Little Smoky, Crooked Creek (T. Pike), 33 
$\mathrm{km} \mathrm{W}$ of Watino, $9.7 \mathrm{~km} \mathrm{~S}$ of Peace River, Boundary Lake, $30 \mathrm{~km} N$ of Bear Canyon, the Peace Hills $6.4 \mathrm{~km} \mathrm{~S}$ of Bear Canyon, Hilliard's Bay on Lesser Slave Lake (W. Smith), Edson (R. L. Anderson), $33 \mathrm{~km} \mathrm{~W}$ of Edson (T. Pike), $9.7 \mathrm{~km}$ NE of Robb, Rock Lake (T. Pike), and $5 \mathrm{~km} \mathrm{~W}$ of Medicine Lodge (T. Pike).

MEADOW CRESCENT (Phyciodes campestris campestris). July 12 . Known by a single collection from the Cadomin area (T. Pike).

ANICIA CHECKERSPOT (Euphydryas anicia anicia). June 19-July 12 . Found in meadows near mixed woods. It is known from the vicinities of Pocahontas ( $K$. Bowman), Rock Lake (T. Pike) and Cadomin (T. Pike).

BEAN'S CHECKERSPOT (Euphydryas editha beani). July 2. It is known only from the Pocahontas vicinity (K. Bowman).

JENISTAI FRITILLARY (Boloria beliona jenistai). May-August 27. Found in aspen woods where violets, the food plants, are common. It is known from the vicinities of Bilby (D. Mackie), Flatbush (R. Carcasson), along the Waskahigan River near Little Smoky and near MacLean Creek $30 \mathrm{~km} \mathrm{~N}$ of Bear Canyon.

FRIGGA FRITILLARY (Boloria frigga saga). May 29-August 17. Found in grassy black spruce-tamarack bogs where willows and cloudberry (Rubus chamaemorus) are common. It is known from the vicinities of Pocahontas (K. Bowman), Robb (T. Pike), Rock Lake (T. Pike), junction of the Grande Cache and Rock Lake roads (T. Pike), Evansburg (T. Pike), $19 \mathrm{~km} \mathrm{~W}$ of Wildwood (T. Pike), $5 \mathrm{~km}$ W of Medicine Lodge (T. Pike), $33 \mathrm{~km}$ W of Edson (T. Pike), $25 \mathrm{~km}$ NW of Whitecourt, $8 \mathrm{~km} E$ of Whitecourt (T. Pike), Fox Creek and Little Smoky.

FREIJA FRITILLARY (Boloria freija freija). May 14-June 19. Found in open, dry pine woods adjacent to black spruce bogs, especially common on stabilized sand dunes. It is known from the vicinities of Cadomin (K. Bowman), Robb (T. Pike), Rock Lake (T. Pike), Flatbush. (F. D. Johanson), $25 \mathrm{~km} \mathrm{NW}$ of Whitecourt, near the losegun River campground and Fox Creek.

PURPLE LESSER FRITILLARY (Bo/oria titania grandis). July 12-August 27 . Found in spruce, pine and mixed forest where willows, one of the food plants are common. It is known from the vicinities of Flatbush (D. Hughes), Bilby (D. Mackie), Whitecourt, $30 \mathrm{~km}$ WNW of Whitecourt, $15 \mathrm{~km} N$ of Windfall, Fox Creek, Pass Creek Tower, Kleskun Hills, $70 \mathrm{~km} \mathrm{~S}$ of Grande
Prairie (G. Hilchie), Robb (C. D. Bird) and Cadomin (K. Bowman and T. Pike).

BOG FRITILLARY (Boloria eunomia). June 11-July 5. Found in black spruce woods and black spruce-peat moss bogs, where it feeds on Labrador tea. It is known from the vicinities of Bilby (D. Mackie), MacLean Creek $30 \mathrm{~km} N$ of Bear Canyon, Evansburg (T. Pike), Nojack (T. Pike), 19 km $W$ of Wildwood (T. Pike), $3 \mathrm{~km}$ E of Entwistle (T. Pike), $2 \mathrm{~km}$ W of Granada (T. Pike), $13 \mathrm{~km} \mathrm{~S}$ of Edson (T. Pike), $5 \mathrm{~km}$ W of Edson (T. Pike), $5 \mathrm{~km} \mathrm{~W}$ of Medicine Lodge (T. Pike), $25 \mathrm{~km}$ E of Rock Lake (T. Pike), Enilda (G. Hilchie), Crooked Creek (T. Pike), 32 $\mathrm{km} \mathrm{E}$ of Grand Prairie (T. Pike), MacLean Creek $30 \mathrm{~km} \mathrm{~N}$ of Bear Canyon and Boundary Lake.

SILVER-BORDERED FRITILLARY (Boloria selene atrocostalis). June 11-August 15. Found in moist areas along edges of mixed deciduous woods where the food plants, violets and strawberries, are common. It is known from the vicinities of Hilliard's Bay on Lesser Slave Lake (W. Smith), Evansburg (T. Pike), Beach Corner (T. Pike), $19 \mathrm{~km} \mathrm{~W}$ of Wildwood (T. Pike), Little Smoky, MacLean Creek, $23 \mathrm{~km}$ WSW of Clear Prairie, Windfall, $32 \mathrm{~km}$ NNW of Windfall, $8 \mathrm{~km} \mathrm{E}$ of Whitecourt (T. Pike), Fox Creek, $46 \mathrm{~km}$ SE of Fox Creek, Crooked Creek (T. Pike), Robb (T. Pike) and $32 \mathrm{~km}$ W of Edson (T. Pike).

MORMON FRITILLARY (Speyeria mormonia eurynome). July 8 -August 15 . Found commonly in parkland areas or in open aspen woods. It is known from the vicinities of Pocahontas (K. Bowman), the Kleskun Hills, Bluesky (C. L. Neilson), Peace River (collected in 1893, possibly by James Fletcher), Huallen (C. L. Neilson), Fairview (C. L. Neilson) and $30 \mathrm{~km} \mathrm{~S}$ of Fox Creek.

ATLANTIS FRITILLARY (Speyeria atlantis). This group appears to be represented locally by three closely related subspecies. All three fly near aspen woods where the food plants, violets, are common, but are in different macrohabitats. Holland's Atlantis Fritillary (Speyeria atlantis hollandi) is common in continuous aspen or mixed woods. It is known from the vicinities of Coalspur, Edson (R. L. Anderson), Windfall, $15 \mathrm{~km} \mathrm{~N}$ of Windfall, $30 \mathrm{~km}$ WNW of Whitecourt, $19 \mathrm{~km}$ NW of Whitecourt, Pass Creek Tower, Fox Creek, $46 \mathrm{~km}$ SE of Fox Creek and the Kleskun Hills. It is known to fly from July 22 to August 27.

The range of Bean's Fritillary (Speyeria atlantis beani) apparently extends northward from southern Alberta along the mountains and thence eastward along 


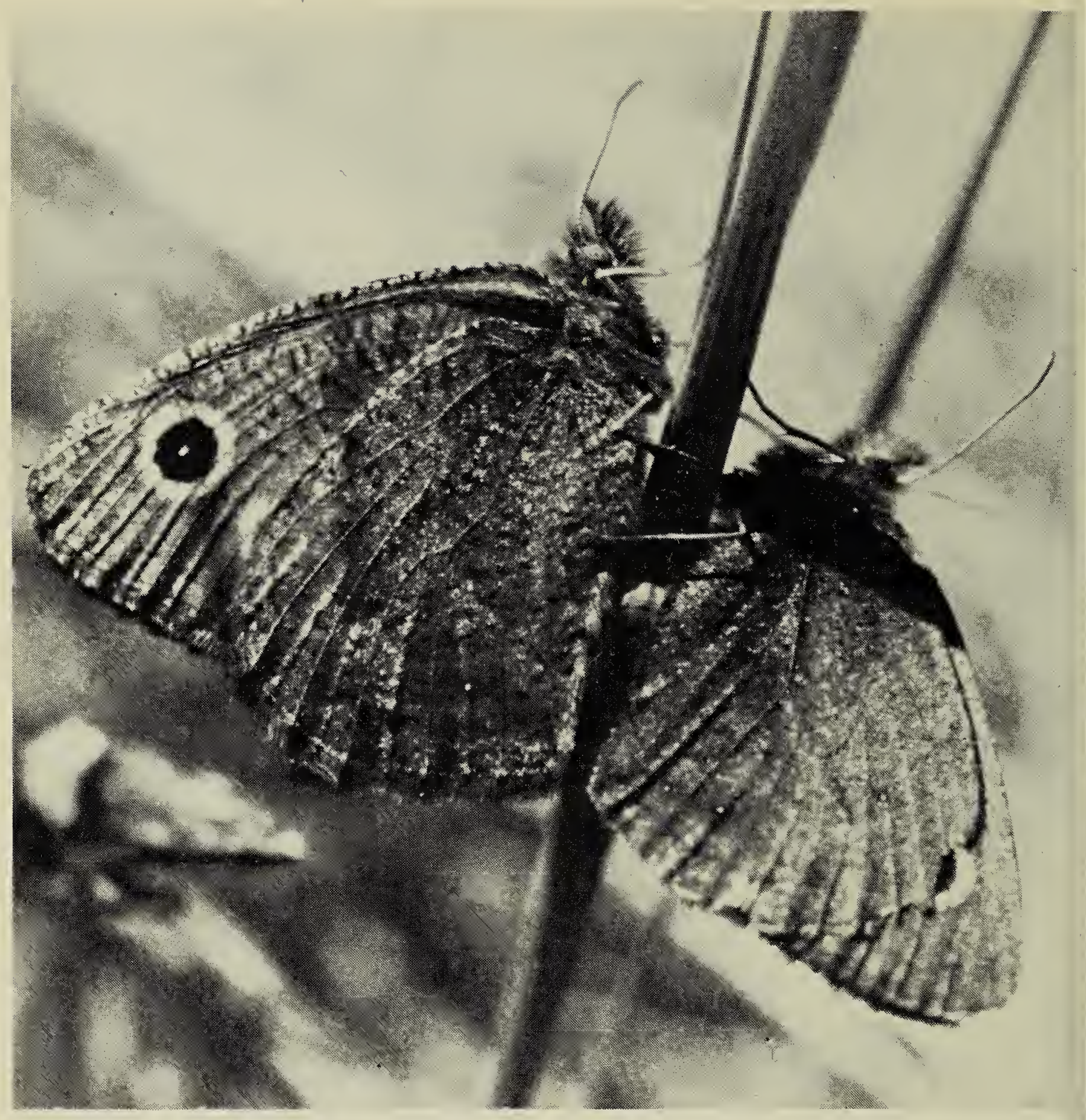

Common Wood Nymph

Gary Anweiler

the major river valleys such as the McLeod, Athabasca and Peace rivers. It is known from the vicinities of Pocahontas (K. Bowman), Robb (C. D. Bird), MacLean Creek $30 \mathrm{~km} \mathrm{~N}$ of Bear Canyon, and $26 \mathrm{~km} \mathrm{~W}$ of Clear Prairie. It is known to fly from July 7 to August 3.

The Northwestern Silverspot (Speyeria atlantis helena) however, seems to be restricted to the edge of aspen bluffs in prairie areas but more observations would be needed to confirm this. Specimens approaching this subspecies are known from the vicinities of Bilby (D. Mackle) and Peace River (James Fletcher). The breaking of land for cultivation has possibly eliminated much of its former habitat.

GREAT SPANGLED FRITILLARY (Speyeria cybele pseudocarpenteri). July 30-August
7. Found in open aspen woods or along the edges of aspen bluffs in parkland. It is known from the vicinities of Bilby (D. Mackie), and George Lake (T. Pike).

HYDASPE FRITILLARY (Speyeria hydaspe sakuntala). August 20. It is known only from the vicinity of Pocahontas (K. Bowman).

\section{SATYRIDAE - The Meadow Browns}

RINGLET (Coenonympha tullia inornata). May 28-July 10 . Found in prairie areas. It is known from the vicinities of Bilby (D. Mackie), Evansburg (T. Pike), Nojack (T. Pike), Crooked Creek (T. Pike), Beaverlodge (K. Bowman), Wembley ( $K$. Bowman), Peace River, Grimshaw and Bear Canyon. 
COMMON WOOD NYMPH (Cercyonis pegala ino). July 22-24. Found in grassy clearjngs at the edges of aspen woods. It is known from the vicinity of Bilby (D. Mackie) and the Kleskun Hills.

VARUNA ARCTIC (Oeneis uhleri varuna). June 8-July 1 . Found in prairie clearings in parkland areas. It is known from the vicinities of Peace River, Beaverlodge (C. L. Neilson), and Dunvegan (K. Bowman).

CARY'S ARCTIC (Oeneis chryxus). June 19-july 12. Found in lodgepole pine woods in areas of sandy soil. It is known only from the vicinity of MacLean Creek $30 \mathrm{~km} \mathrm{~N}$ of Bear Canyon, Cadomin (T. Pike) and Rock Lake (T. Pike). The specimens from MacLean Creek closely resemble Oeneis chryxus caryi.

MACOUN'S ARCTIC (Oeneis macounii). June 16-July 1 . Found rarely in lodgepole pine and white spruce woods. It is known from the vicinities of Bear Canyon and Boundary Lake in the Peace River district. This species is named in honour of the famous Canadian naturalist, John Macoun (1831-1920), who explored the natural history of that area off and on between 1872-1875.

JUTTA ARCTIC (Oeneis jutta). June 11-July 12. Found in black spruce bogs. It is known from the vicinities of Bilby (D. Mackie), 19 $\mathrm{km} \mathrm{W}$ of Wildwood (T. Pike), $13 \mathrm{~km} \mathrm{~S}$ of Edson (T. Pike), $5 \mathrm{~km} \mathrm{~W}$ of Medicine Lodge (T. Pike) and Fox Creek.

BEAN'S ARCTIC (Oeneis melissa beanii. July 2-July 12 . Found in mountain areas of western Alberta. It is known only from the vicinity of Pocahontas (K. Bowman).

BRUCE'S ARCTIC (Oeneis polixenes brucei). June 29-July 12. Found above timberline in alpine meadows. It is known from the vicinities of Roche Miette (K. Bowman and Pocahontas (K. Bowman).

COMMON ALPINE (Erebia epipsodea). May 28-July 12 . Found commonly in open prairie and near aspen bluffs in parkland. Three collections were made in the Peace River area in 1883 but the collector is unknown. It is also known from the vicinities of Beach Corner (T. Pike), Evansburg ( $T$. Pike), Fox Creek, Little Smoky, Valleyview, Peace River, Grimshaw (T. Pike), Beaverlodge (K. Bowman), MacLean Creek $30 \mathrm{~km} \mathrm{~N}$ of Bear Canyon, $13 \mathrm{~km} \mathrm{~S}$ of Edson (T. Pike), Rock Lake (T. Pike), $5 \mathrm{~km}$ $W$ of Medicine Lodge (T. Pike), Cadomin (T. Pike) and Pocahontas (K. Bowman).

MANCINUS ALPINE (Erebia disa mancinus). June 3-July 5. Found occasionally in black spruce woods or black sprucesphagnum bogs. It is known from the vicinities of Bilby (D. Mackie), $19 \mathrm{~km} \mathrm{~W}$ of
Wildwood (T. Pike), Fox Creek, $19 \mathrm{~km}$ SE of Little Smoky, $13 \mathrm{~km} \mathrm{~S}$ of Edson (T. Pike), 5 $\mathrm{km} \mathrm{W}$ of Medicine Lodge (T. Pike), Rock Lake (T. Pike), the junction of the Grand Cache and Rock Lake roads (T. Pike) and Pocahontas (K. Bowman).

RED DISKED ALPINE (Erebia discoidalis macdunnoughi). May 18-June 19. Rarely seen in some years, but in others it is abundant in prairie meadows, along cutlines through aspen woods and occasionally in dry pine woods, where grasses, the food plants, are abundant. It is known from the vicinities of Flatbush ( $R$. Carcasson, M. A. MacGregor), Rock Lake (T. Pike) and Fox Creek.

\section{Expected Species List}

A number of additional species are still likely to be found in the area. Most could be near the limits of their range. Future workers in the area should be on the lookout for the Roadside Skipper (Amblyscirtes vialis), Assiniboia Skipper (Hesperia comma assiniboia), Boreal Skipper (Hesperia comma borealis), Garita Skipper (Oarisma garita), Two Banded Skipper (Pyrgus ruralis), Northern Skipper (Polites draco), California White (Pieris sisymbril flavitincta), Phlaeas Copper (Lycaena phlaeas arethusa), Snow's Copper (Lycaena snowi), Great Copper (Lycaena xanthoides), Rustic Arctic Blue (Plebejus aquilo rustica), American Painted Lady (Cynthia virginiensis), California Tortoise Shell (Nymphalis californica), Variegated Fritillary (Euptoieta claudia claudia), Monarch (Danaus plexippus plexippus), and the Alberta Arctic (Oeneis alberta alberta).

'CANADIAN ARCTIC GAS PIPELINE COMMITTEE (eds.) 1973-1977. Arctic Gas Biological Report Series. 37 Vols. Calgary

${ }^{2}$ FERRIS, C. D. 1972. Notes on certain species of Colias (LEPIDOPTERA: PIERIDAE) found in Wyoming and associated regions. Bull. Allyn Mus., No. 6. 23 pp.

${ }^{3}$ HOOPER, R. R. 1973. Butterflies of Saskatchewan. Saskatchewan Dept. of Natural Resources. Regina. 216 pp.

${ }^{4}$ HOWE, W. (ed.) 1975. The Butterflies of North America. Doubleday. and Company, Inc. Garden City, New York 633 pp.

${ }^{5}$ MOSS, E. H. 1955 . The vegetation of Alberta. Bot. Rev. 21(9): 493-567.

${ }^{6}$ MOSS, E. H. 1959. Flora of Alberta. University of Toronto Press, Toronto. $546 \mathrm{pp}$. 